\title{
Literasi Pelaporan Keuangan Pengurus Masjid Untuk Meningkatkan Transparansi Dan Akuntabilitas Keuangan Masjid
}

\author{
Ulfi Maryati ${ }^{1}$, Sukartini $^{2}$, Amy Fontanella $^{3}$, Armel Yentifa ${ }^{4}$, dan Ermataty Hatta ${ }^{5}$
}

\author{
${ }^{1} J u r u s a n$ Akuntansi, Politeknik Negeri Padang \\ Email: ulfimaryati@gmail.com \\ ${ }^{2}$ Jurusan Akuntansi, Politeknik Negeri Padang \\ Email: tiensukartini28@gmail.com \\ ${ }^{3}$ Jurusan Akuntansi, Politeknik Negeri Padang \\ Email: amyfontanella99@gmail.com \\ ${ }^{4}$ Jurusan Akuntansi, Politeknik Negeri Padang \\ Email: armelyentifa@gmail.com \\ ${ }^{5}$ Jurusan Akuntansi, Politeknik Negeri Padang \\ Email: ermatati.hatta@gmail.com
}

\begin{abstract}
Increasing the financial literacy of mosque administrators plays an important role to increase accountability and transparency in managing mosque finance. It is caused the mosque functions not only as a place of worship but also as a center for social activities of the community using funds originating from the community. Every rupiah of community funds used must be accounted to the community. Therefore, the existence of accounting used in the process of recording and preparing mosque financial reports is very vital.

This Community service is held at the Imaduddin Mosque, which is one of the educational reference mosques in Padang. All this time, the mosque administrators managed funds in a very large amount. However, the management of these funds has not been supported by adequate financial recording and reporting, which make dissatisfaction to the funders. This is due to the limited competence of HR management and lack of understanding about recording and financial statements. To solve this problems, training will be provided for recording and preparing financial reports and simple applications for preparing financial statements.

The output of this community service is to increase financial literacy and to train mosque administrators in recording and preparing financial reports. The approach offered to the partner is workshops and financial report training for non-profit organizations using Microsoft Excel. It is also produced a financial report preparation module which can be guided by the mosque management.
\end{abstract}

Keywords: Mosque, accountability, transparency

Peningkatan literasi keuangan pengurus masjid berperan sangat penting sebagai upaya peningkatan akuntabilitas dan transparansi pengelolaan keuangan masjid. Hal ini disebabkan karena masjid yang menjalankan fungsi tidak hanya sebagai tempat peribadatan tetapi juga sebagai pusat aktivitas sosial masyarakat menggunakan dana yang bersumber dari masyarakat. Setiap satu rupiah dana umat yang digunakan harus dipertanggungjawabkan pengelolaannya kepada masyarakat. Oleh karena itu keberadaan akuntansi yang digunakan dalam proses pencatatan dan penyusunan laporan keuangan masjid menjadi sangat vital. Pengabdian masyarakat ini dilakukan pada Masjid Imaduddin yang merupakan salah satu masjid rujukan pendidikan di Kota Padang. Selama ini pengurus masjid melakukan pengelolaan dana dalam jumlah yang sangat besar. Namun pengelolaan dana ini belum didukung oleh pencatatan dan pelaporan keuangan yang memadai sehingga acapkali menimbulkan ketidakpuasan penyandang dana. Hal ini disebabkan karena terbatasnya kompetensi SDM pengurus 
dan kurangnya pemahaman tentang pentingnya pencatatan dan laporan keuangan.Oleh karena itu untuk membantu mitra menyelesaikan permasalahannya akan diberikan pelatihan pencatatan dan penyusunan laporan keuangan serta aplikasi sederhana untuk menyusun laporan keuangan.

Luaran yang akan dihasilkan dari kegiatan pengabdian ini adalah peningkatan literasi keuangan serta terlatihnya pengurus masjid dalam melakukan pencatatan dan penyusunan laporan keuangan. Pendekatan yang ditawarkan pada mitra adalah; melakukan workshop dan pelatihan penyusunan laporan keuangan bagi organisasi nirlaba dengan menggunakan Microsoft excel. Selain itu juga akan dihasilkan modul penyusunan laporan keuangan yang dapat dipedomani oleh pengurus masjid.

Kata Kunci : Masjid, akuntabilitas, transparansi

\section{Pendahuluan}

Penguatan fungsi masjid memiliki dampak positif bagi pembinaan masyarakat dan pengembangan syi'ar Islam khususnya. Hal ini disebabkan karena mesjid tidak hanya berfungsi sebagai tempat ibadah, tetapi lebih jauh juga memiliki fungsi sosial sebagai pusat interaksi masyarakat dan juga fungsi pendidikan sebagai tempat belajar keislaman dan keilmuan. Fungsi masjid harus dimaknai dalam berbagai dimensi, seperti sebagai pusat pemberdayaan masyrakat dan peningkatan ekonomi umat, seperti penyenggara baitul mal, unit pelayanan zakat, infak dan shodaqah. Oleh karena itu pengelola masjid harus menyadari bahwa masjid menyimpan potensi yang sangat besar jika digunakan secara optimal untuk meningkatkan kesejahteraan umat, sekurang kurangnya bagi jamaah masjid itu sendiri.

Pentingnya peran dan fungsi masjid bagi kesejahteraan umat membutuhkan transparansi dan akuntabilitas dalam pengelolaannya. Hal ini disebabkan karena masjid merupakan entitas akuntansi yang semua aktivitasnya harus dipertanggungjawabkan kepada publik. Masjid mengelola dan menggunakan dana yang bersumber dari masyarakat sebagai sumber keuangannya baik dalam bentuk sumbangan, sedekah atau bantuan lainnya. Oleh karena itu transparansi dan akuntabilitas menjadi kata kunci bagi masjid untuk dapat bertahan dan memaksimalkan perannya pada domain sosial budaya.

Agar dapat mewujudkan transparansi dan akuntabilitas pengelolaan keuangan masjid diperlukan eksistensi pengurus masjid yang memiliki literasi keuangan yang memadai. Adanya sistem informasi akuntansi dan pembukuan serta laporan keuangan masjid akan memudahkan dalam pengambilan keputusan tentang pembangunan dan pemberdayaan pengelolaan masjid. Selain itu, pengurus masjid juga perlu menyampaikan informasi yang dapat meningkatkan kredibilitasnya walaupun posisi tersebut hanya sebatas kerelaan. Literasi keuangan yang dimiliki oleh pengurus dan penyajian laporan keuangan yang akuntabel nerupakan salah satu upaya yang dapat ditempuh untuk mengurangi asymmetri informasi antara pengurus masjid dan masyarakat disekitarnya.

Dari sisi akuntansi, kehadiran PSAK No.45 tentang Akuntansi untuk organisasi nirlaba yang diterbitkan oleh Ikatan Akuntan Indonesia (IAI) memungkinkan pengurus masjid untuk meningkatkan akuntabilitas dan transparansi pencatatan dan pelaporan keuangannya mengacu pada standar ini. Namun sayangnya, tidak banyak pihak yang memahami bahwa sudah ada standar yang dapat dijadikan sebagai patokan dalam pengelolaan keuangan masjid ini.

Masjid Imaduddin merupakan salah satu masjid yang belum melakukan pencatatan dan pelaporan keuangan sesuai dengan PSAK No.45 ini. Masjid Imaduddin terletak di Wisma Indah II Kelurahan Lapai Kecamatan Nanggalo, dan merupakan salah satu Masjid rujukan untuk pendidikan di Kota Padang. Selama ini tempat shalat 
berada dilantai 2 mesjid dan lantai dasar digunakan sebagai kelas-kelas Taman Pendidikan Al-Quran (TPA/TPQ). Aktifitas keseharian masjid dibiayai dari infak, sedeqah dan sumbangan dari masyarakat sekitar. Saat ini sedang dilakukan kegiatan renovasi masjid dengan menggunakan dana yang bersumber dari masyarakat. Pengurus masjid berjumlah lebih kurang 30 orang dengan dominasi pengurus berusia lanjut. Masjid ini mengelola dana dalam jumlah yang cukup besar namun belum didukung oleh pembukuan dan laporan keuangan. Oleh karena itu diperlukan peningkatan literasi keuangan pengurus masjid agar transparansi dan akuntabilitas pengelolaan keuangan masjid juga meningkat.

\section{Permasalahan}

Pengurus masjid Imaduddin dalam aktivitasnya mengelola dana sumbangan, zakat, infaq, sadaqah dan dana lainnya dalam jumlah yang cukup besar. Karena dana tersebut bersumber dari masyarakat idealnya juga disertai oleh pengelolaan keuangan yang transparan dan akuntabel. Namun pada realitasnya saat ini, pencatatan keuangan masjid baru terbatas pada pencatatan sumbangan di papan pengumuman. Pencatatan ini juga tidak dilakukan secara konsisten dan berkala oleh pengurus. Sampai saat ini belum dilakukan penyusunan laporan keuangan masjid yang memadai. Kondisi ini tidak jarang menyebabkan terjadinya ketidakpuasan dikalangan masyarakat yang menjadi donator masjid.

Tidak adanya pencatatan dan laporan keuangan ini disebabkan oleh beberapa faktor antara lain:

1. Kurangnya kesadaran pengurus terhadap pentingnya pencatatan dan penyusunan laporan keuangan terhadap akuntabilitas dan transparansi pengelolaan masjid

2. Minimnya pemahaman pengurus masjid dalam hal pencatatan dan penyusunan laporan keuangan masjid.

3. Tidak adanya alat bantu/aplikasi sederhana yang memadai dalam pencatatan dan penyusunan laporan keuangan masjid.

\section{Hasil dan Pembahasan}

Perancangan program merupakan tahap penterjemahan dari kebutuhan sistem yang diperlukan untuk mempermudah pekerjaan pengguna aplikasi. Aplikasi akuntansi ini akan dirancang dengan menggunakan software Microsoft Excel 2010. Tahap pertama dalam perancangan pengelolaan keuangan ini adalah menganalisis kebutuhan informasi pengguna. Kemudian tahap keduanya adalah merancang format apa saja yang akan dibutuhkan dalam menyusun laporan keuangan.

\section{Aplikasi Microsoft Excel untuk Masjid Imaduddin.}

Format yang akan dibuat untuk aplikasi ini adalah sebagai berikut :

\section{Format Menu}

Format Data Masjid

Format Data Pengurus

Format Perkiraan

Format Neraca Saldo

Format Kas Masjid

Format Kas Anak Yatim 
* Format Kas MDTA

Format Jurnal Penyesuaian

Format Buku Besar

Format Neraca Lajur

Format Laporan Aktivitas

Format Laporan Posisi Keuangan

Format Laporan Arus Kas

Format Jurnal Penutup

Format Neraca Saldo Akhir

Format Daftar Aset Masjid

\section{Pembuatan Format Menu}

Format ini berisi tentang daftar menu utama dalam aplikasi program yang dibuat.

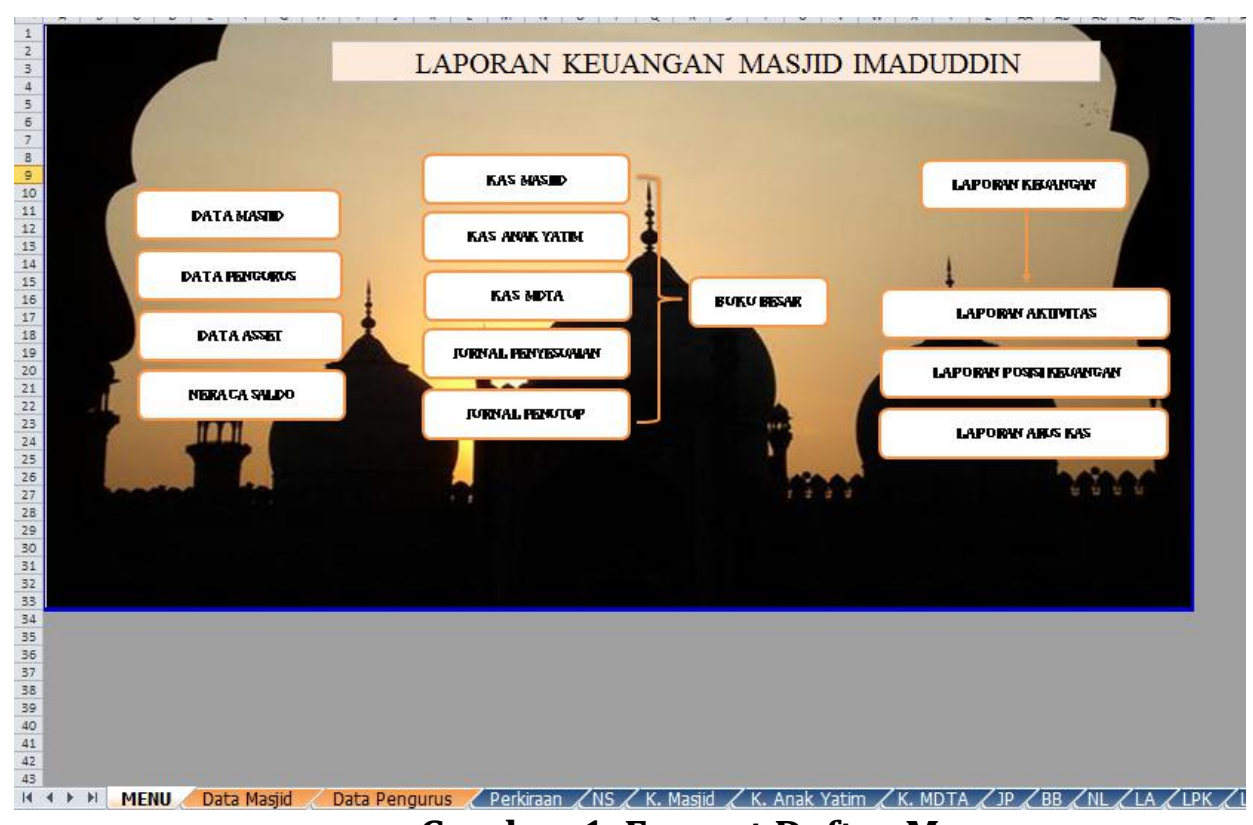

Gambar 1. Format Daftar Menu

\section{Pembuatan Format Data Masjid}

Format ini berisi tentang informasi umum masjid dan sejarah serta perkembangan masjid. 


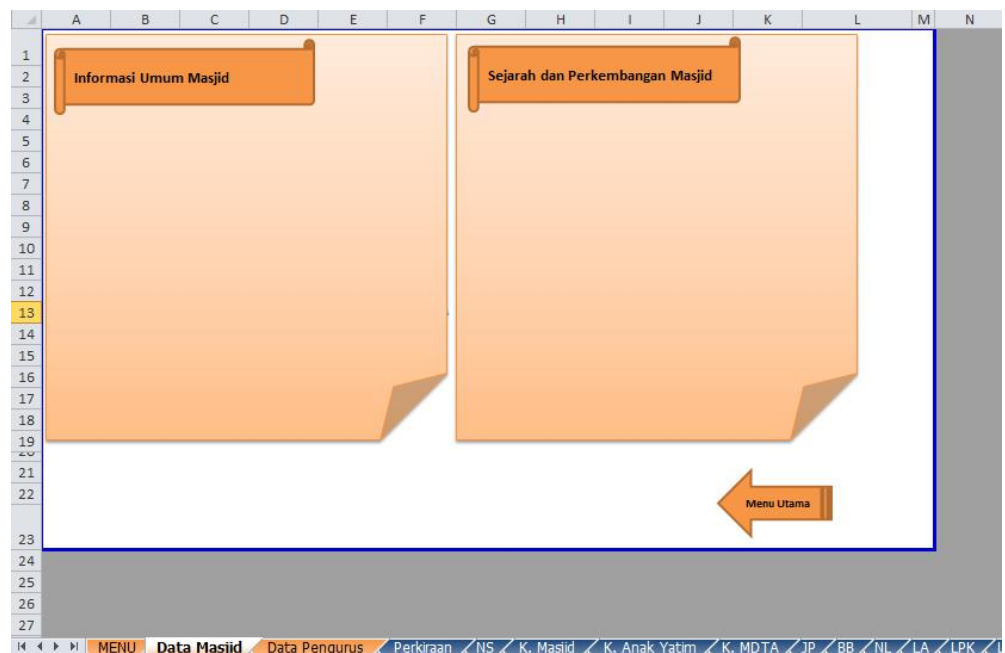

Gambar 2. Format Data Masjid

\section{Pembuatan Format Data Pengurus Masjid}

Format ini berisi tentang daftar data pengurus masjid.

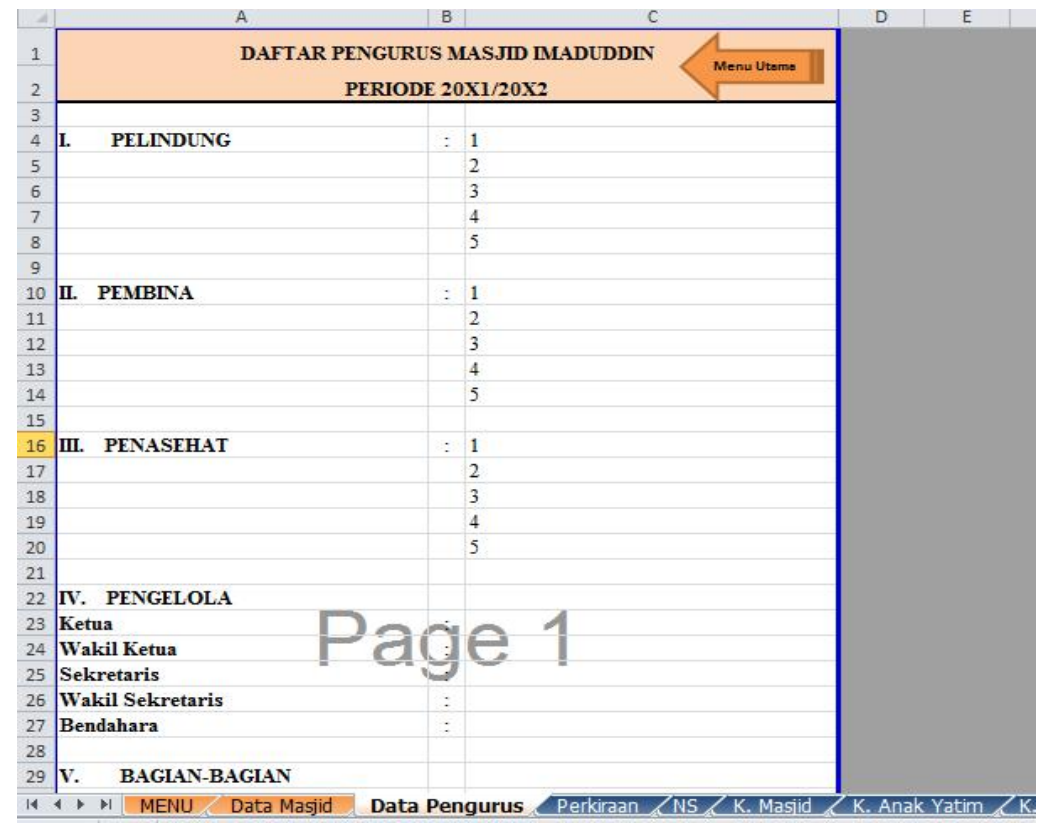

Gambar 3. Format Data Pengurus Masjid

\section{Pembuatan Format Daftar perkiraan}

Format ini berisi tentang daftar kode akun dan nama akun 


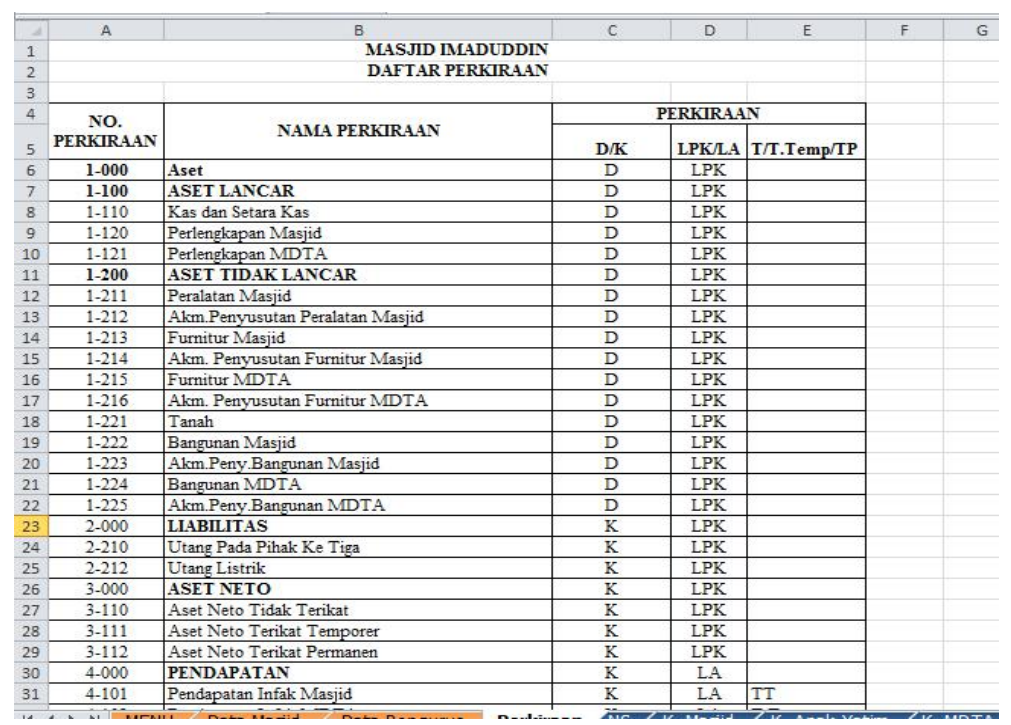

\section{Gambar 4. Format Daftar Perkiraan}

\section{Pembuatan Format Neraca Saldo}

Format ini berisi tentang daftar nama akun beserta saldo masing-masing akun pada periode tersebut.

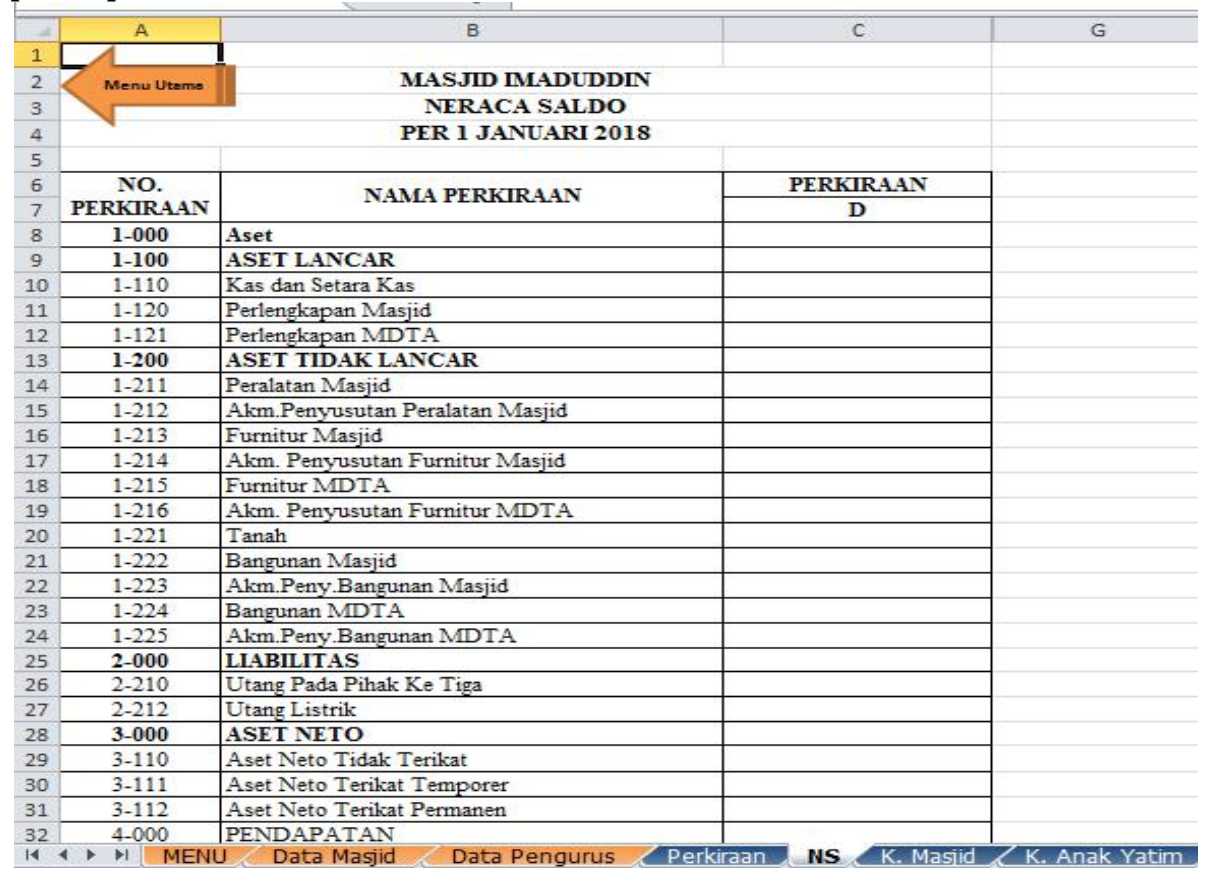

\section{Gambar 5. Format Neraca Saldo}

\section{Pembuatan Format Kas Masjid}

Format ini berfungsi untuk merekam transaksi kas yang terjadi 


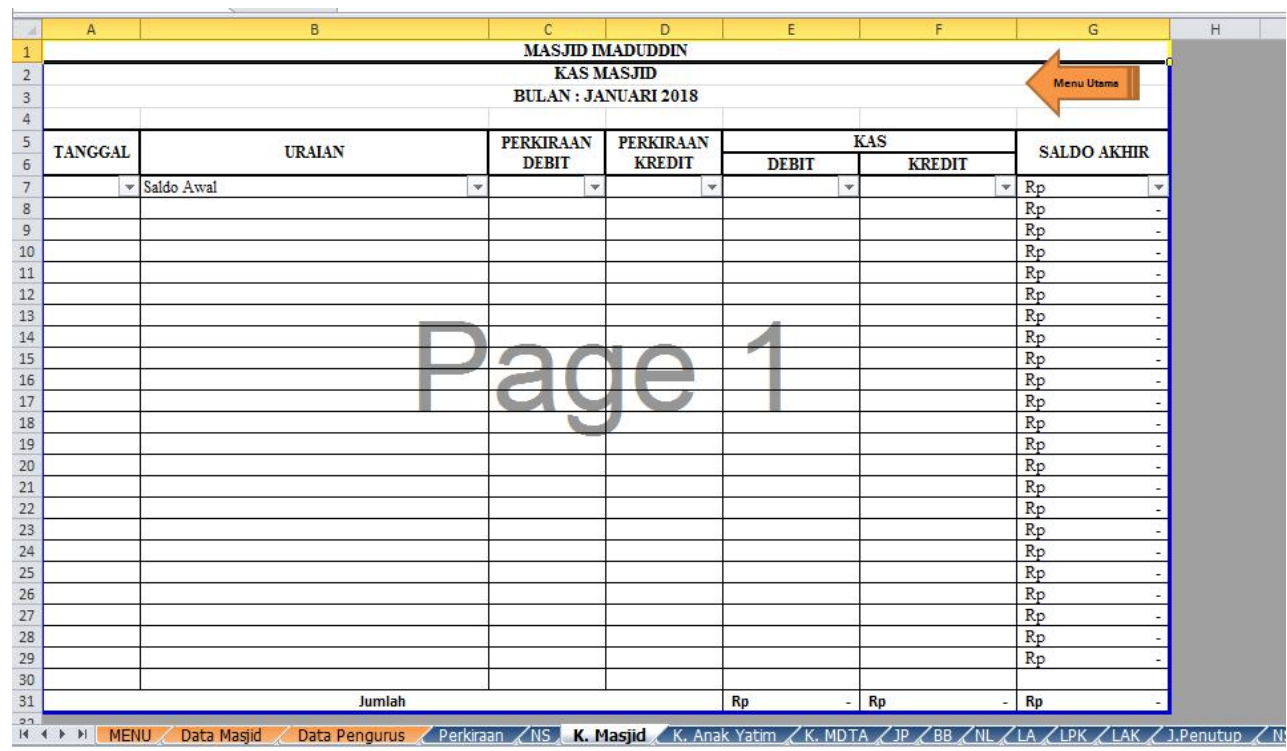

Gambar 6. Format Kas Masjid

\section{Pembuatan Format Kas Anak Yatim}

Format ini berfungsi untuk merekam transaksi kas anak yatim yang terjadi

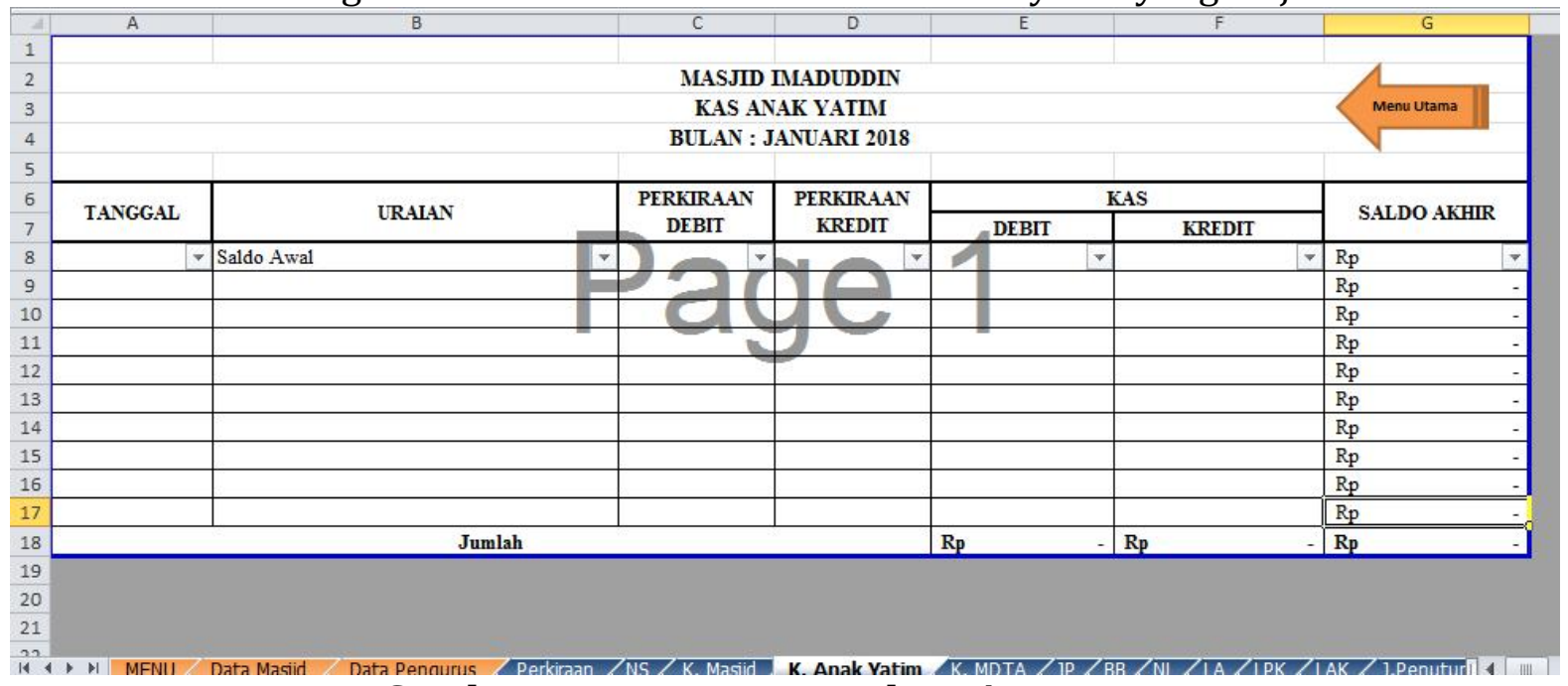

Gambar 7. Format Kas Anak Yatim

\section{Pembuatan Format Kas MDTA}

Format ini berfungsi untuk merekam transaksi kas MDTA yang terjadi 


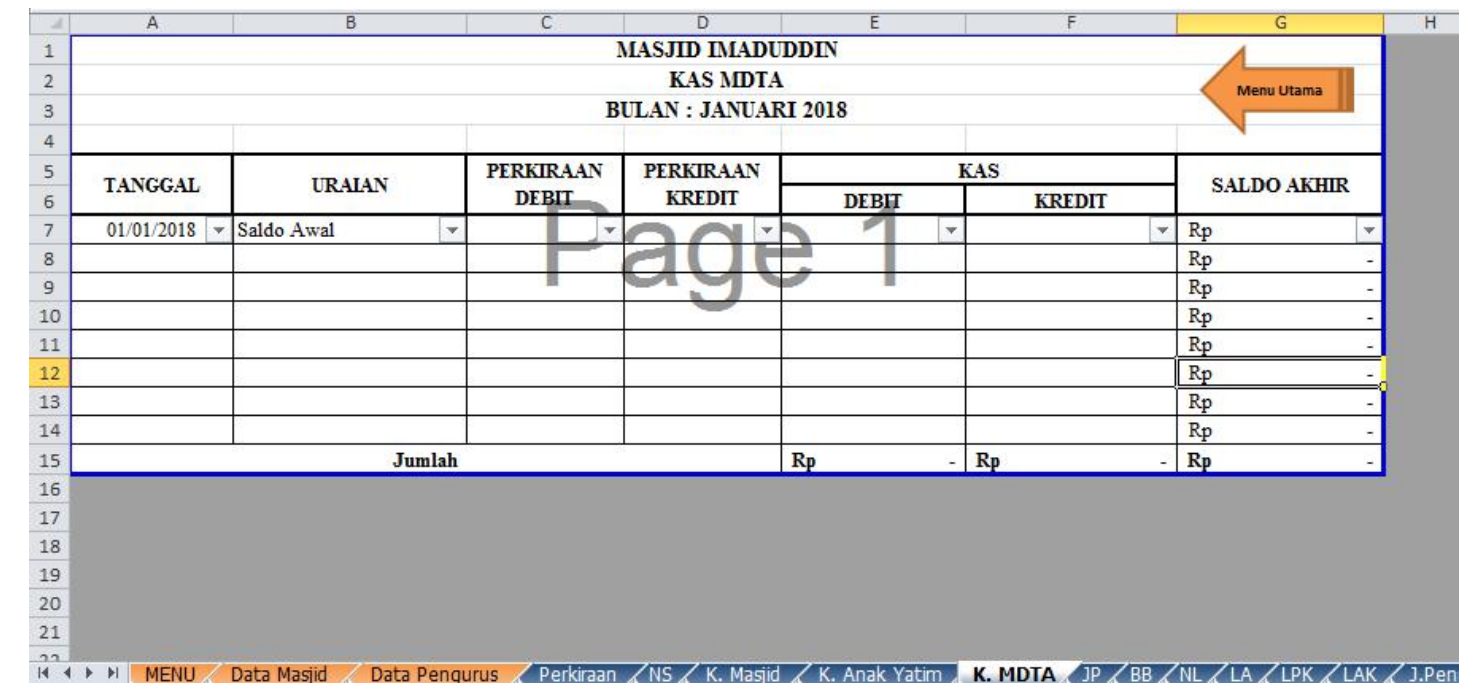

Gambar 8. Format Kas MDTA

\section{Pembuatan Format Jurnal Penyesuaian}

Format ini berfungsi untuk merekam transaksi-transaksi yang terjadi pada Masjid yang perlu disesuaikan.

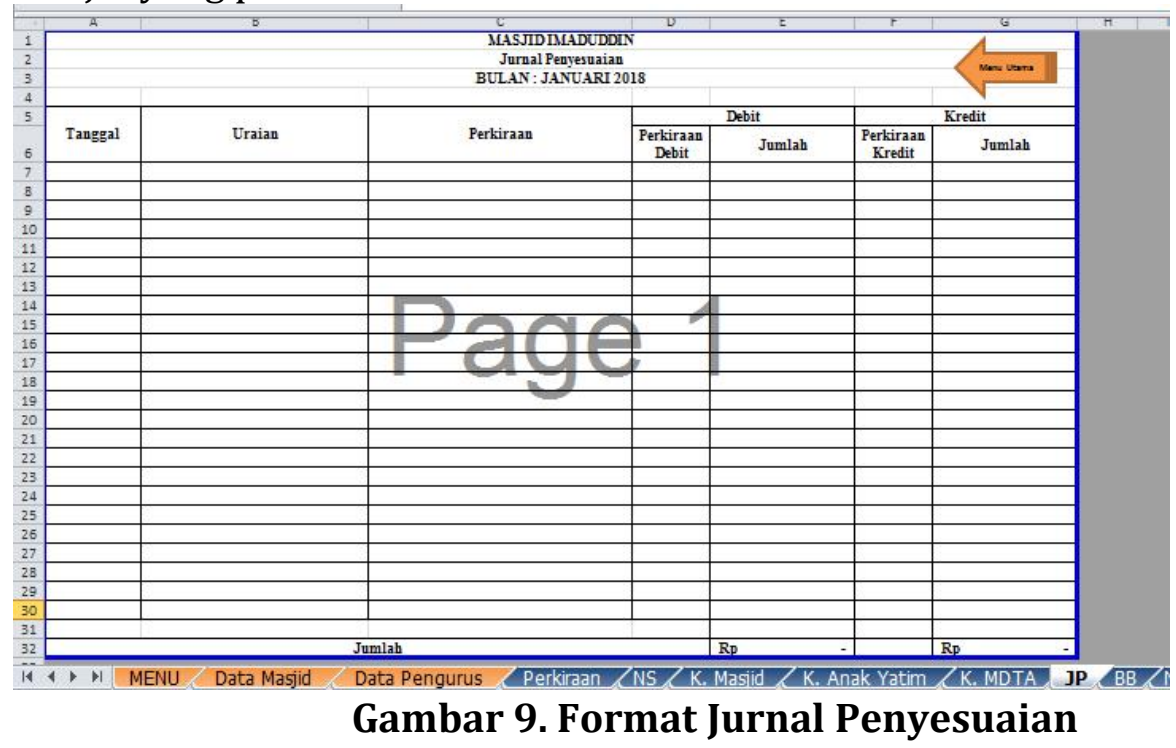

\section{Pembuatan Format Buku Besar}

Format ini akan menampilkan ringkasan dari transaksi yang telah dicatat dalam sheet jurnal. 


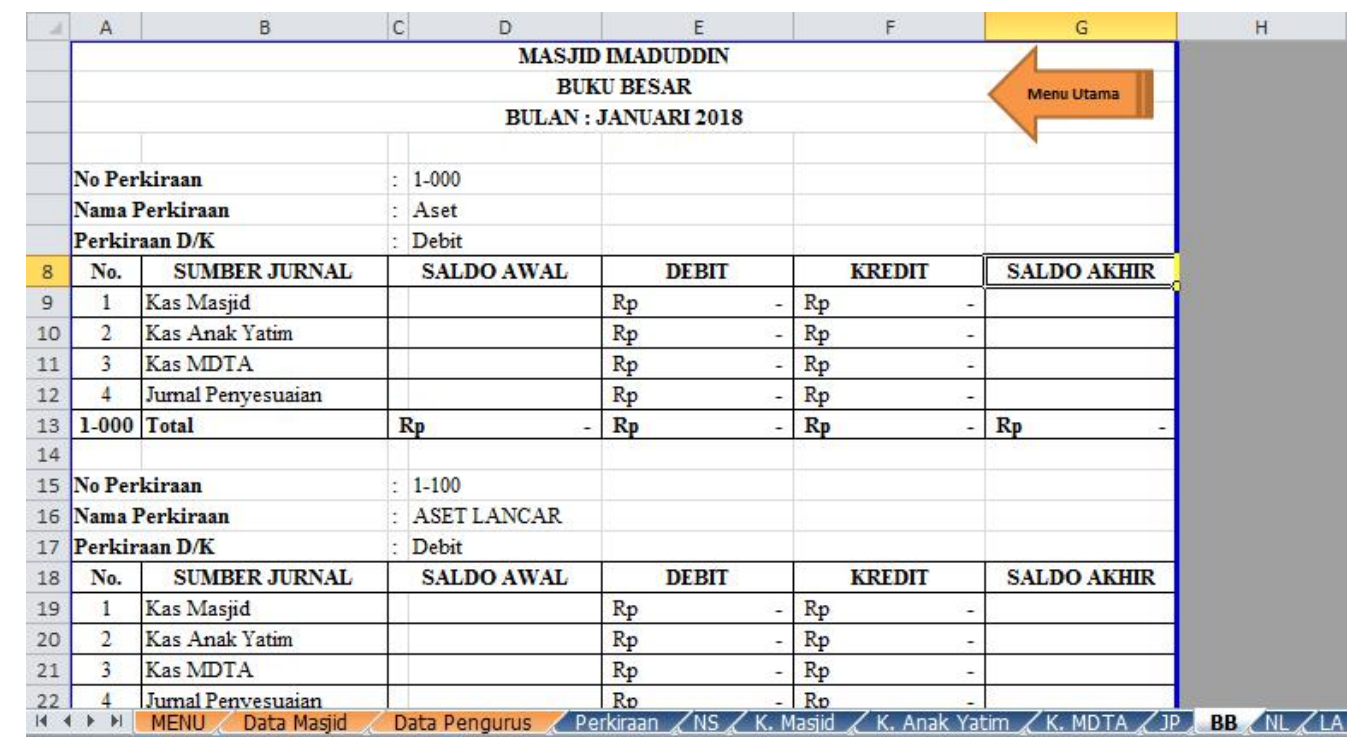

Gambar 10. Format Buku Besar

\section{Pembuatan Format Neraca Lajur}

Format ini berisi ringkasan informasi yang berasal dari neraca saldo yang kemudian dilakukan penyesuaian oleh pengguna lalu secara otomatis kolom Neraca Saldo Disesuaikan akan menampilkan saldo akun yang telah disesuaikan.

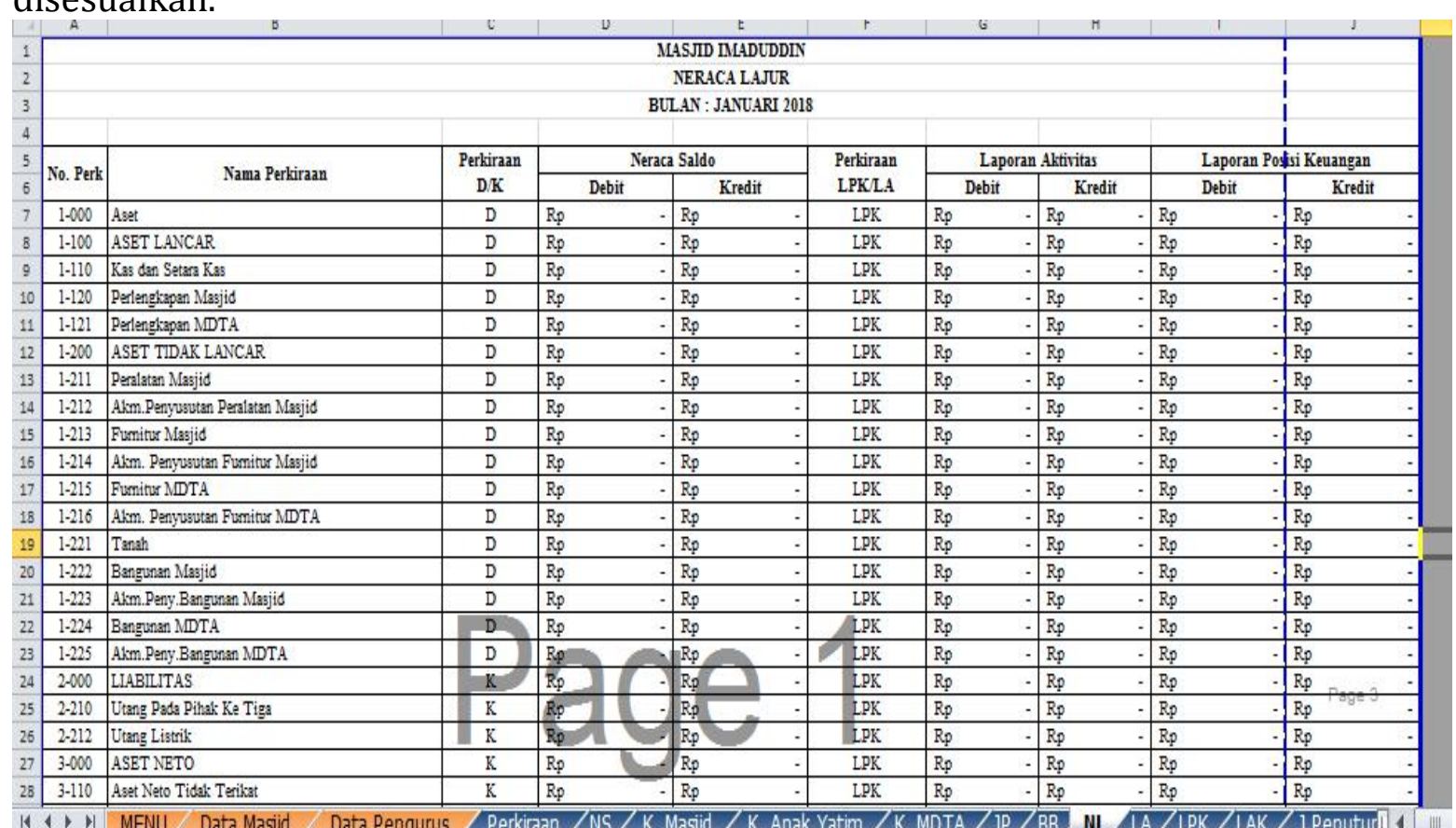

\section{Gambar 11. Format Neraca Lajur}

\section{Pembuatan Format Laporan Aktivitas}

Format ini menyajikan informasi mengenai pendapatan dan beban usaha Masjid selama periode tertentu. 


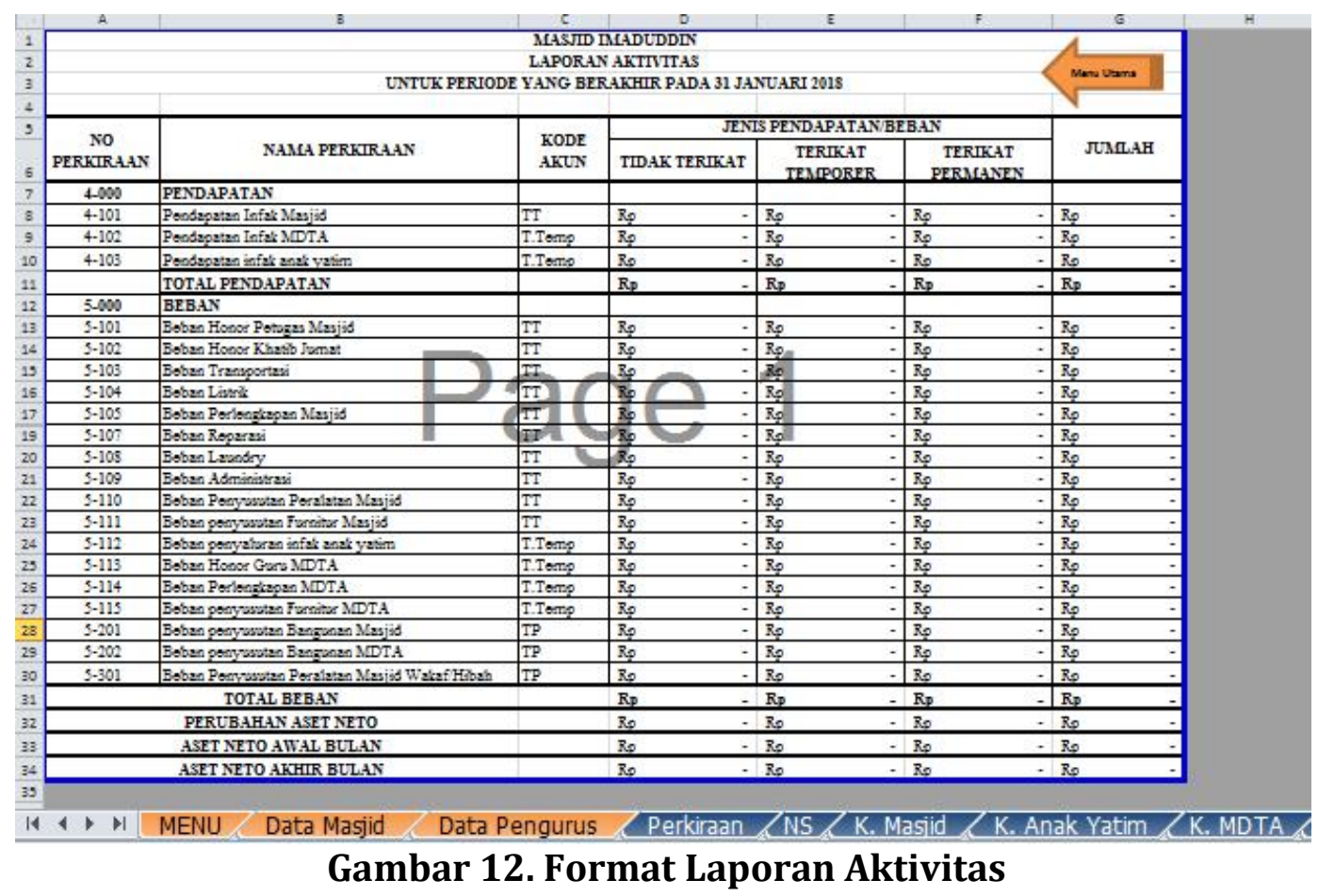

\section{Pembuatan Format Laporan Posisi Keuangan}

Format ini merupakan laporan yang berisi aset, aset tidak lancar, liabilitas dan asset netto selama periode tertentu.

\begin{tabular}{|c|c|c|c|c|c|c|c|c|c|}
\hline 1 & \multicolumn{9}{|c|}{ MASJID IMADUDDIN } \\
\hline 2 & \multicolumn{7}{|c|}{ LAPORAN POSISI KEUANGAN } & & \\
\hline 3 & \multirow{2}{*}{\multicolumn{7}{|c|}{ PER 31 JANUARI 2018}} & & \\
\hline 4 & & & & & & & & & \\
\hline 5 & $\begin{array}{c}\text { No } \\
\text { PERKIRAAN }\end{array}$ & NAMA PERKIRAAN & & & $\begin{array}{c}\text { No. } \\
\text { PERKIRAAN }\end{array}$ & NAMA PERKIRAAN & & & \\
\hline 6 & $1-000$ & Aset & & & $2-000$ & LIABILITAS & & & \\
\hline 7 & $1-100$ & ASET LANCAR & & & $2-210$ & \begin{tabular}{|l|} 
Utang Pada Pihal: Ke Tiga \\
\end{tabular} & $R_{p}$ & & \\
\hline B & $1-110$ & Kas dan Setara Kas & $R p$ & - & $2-212$ & Utang Listrik & $R_{p}$ & & \\
\hline 9 & $1-120$ & Perlengkapan Masjid & $R_{p}$ & - & & & $R_{p}$ & & \\
\hline 10 & $1-121$ & Perlengkapan MDTA & $R_{p}$ & - & & & & & \\
\hline 11 & & & $\mathrm{Rp}_{\mathrm{p}}$ & -1 & & & & & \\
\hline 12 & $1-200$ & ASET TIDAK L.ANCAR & & & & & & & \\
\hline 13 & $1-211$ & Peralatan Masjid & $R_{p}$ & - & $3-000$ & ASET NETO & & & \\
\hline 14. & $1-212$ & Akm.Penyusutan Peralatan Masjid & $R_{p}$ & - & $3-110$ & Aset Neto Tidak Terikat & $\mathrm{Rp}_{\mathrm{p}}$ & & \\
\hline 15 & $1-213$ & Fumitur Masjid & $R_{p}$ & -1 & 3-111 & Aset Neto Terikat Temporer & $R_{p}$ & & \\
\hline 16 & $1-214$ & Alkm. Penyusutan Fumitur Masjid & $R p$ & - & 3-112 & Aset Neto Terikat Pemanen & $R_{p}$ & & \\
\hline 17 & $1-215$ & Funitur MDTA & $R_{p}$ & - & & & $\mathrm{Rp}$ & & \\
\hline 18 & $1-216$ & Akm. Penyusutan Fumitur MDTA & $R_{p}$ & - & & & & & \\
\hline 19 & $1-221$ & Tanah & $R_{p}$ & - & & & & & \\
\hline 20 & $1-222$ & Bangunan Masjid & $R_{p}$ & - & & & & & \\
\hline 21 & $1-223$ & Akm. Peny.Bangunan Masjid & $R_{p}$ & -1 & & & & & \\
\hline 22 & $1-224$ & Bangunan MDTA & $R_{p}$ & - & & & & & \\
\hline 23 & $1-225$ & Alkm.Peny.Bangunan MDTA & $R_{p}$ & 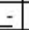 & & & & & \\
\hline 24 & & & $\mathrm{Rp}_{\mathrm{p}}$ & - & & & & & \\
\hline 25 & & & & & & & & & \\
\hline 26 & & & & & & & & & \\
\hline 27 & & TOTAL ASET & $\mathrm{Rp}$ & -1 & TOTAL LIA & ABILITAS DAN ASET NETO & $\mathrm{Rp}_{\mathrm{p}}$ & & \\
\hline
\end{tabular}

Gambar 13. Format Laporan Posisi Keuangan

\section{Pembuatan Format Laporan Arus Kas}

Format ini merupakan laporan yang berisi aliran kas dari koperasi selama periode tertentu. 


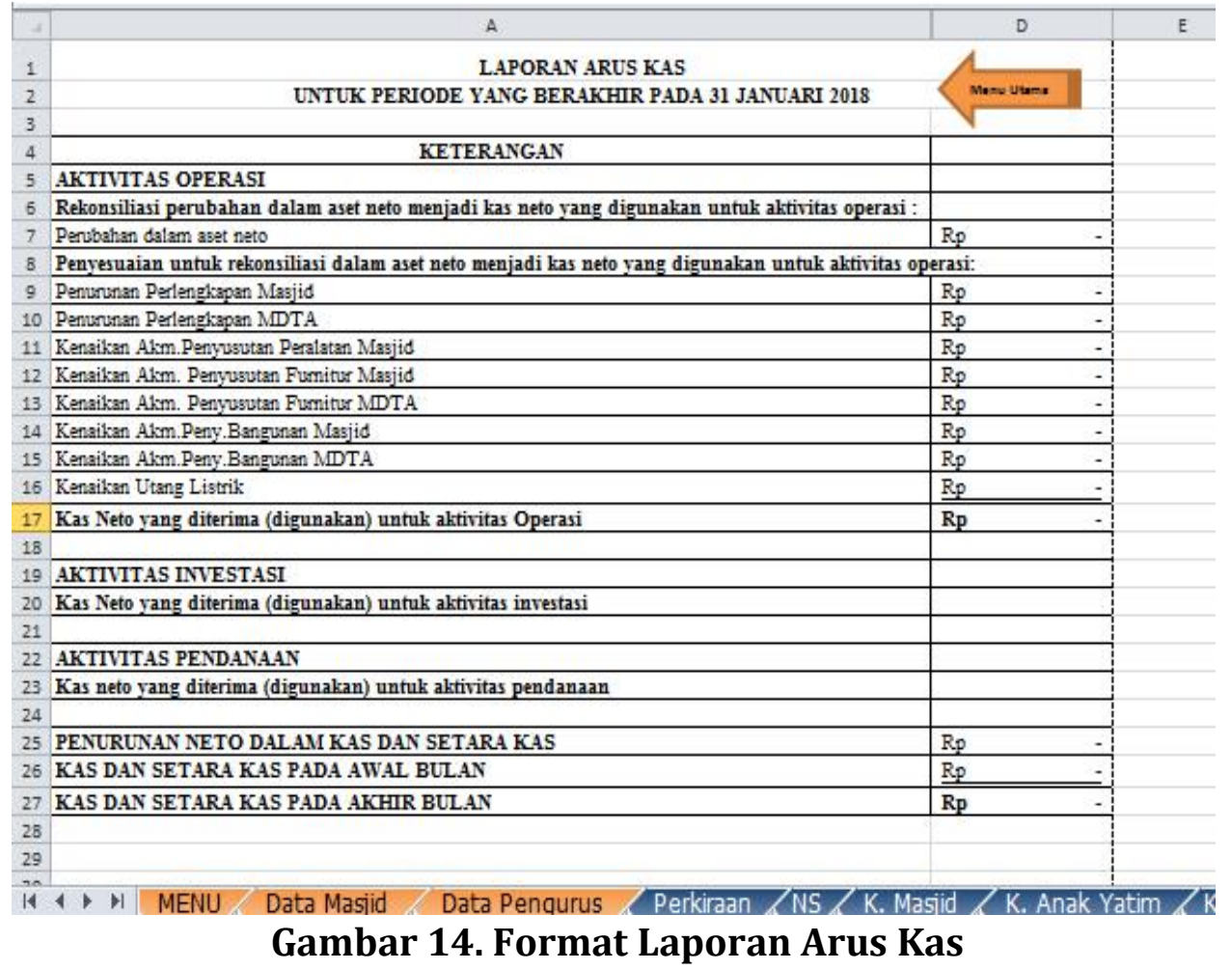

\section{Pembuatan Format Jurnal Penutup}

Format ini berfungsi untuk menutup saldo-saldo akun Masjid Imaduddin di akhir bulan.

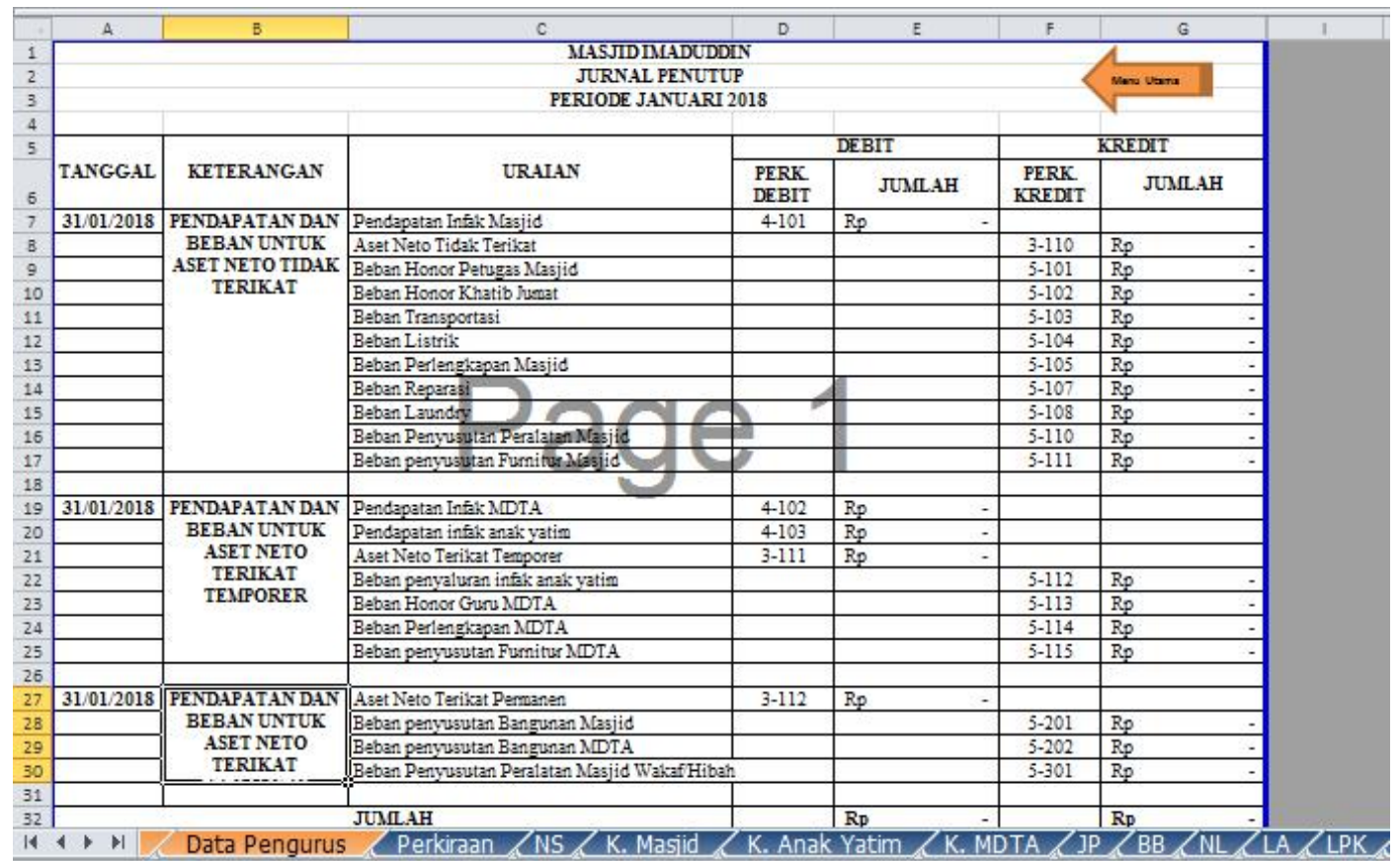

\section{Gambar 15. Format Jurnal Penutup}

\section{Pembuatan Format Neraca Saldo Akhir}

Format ini merupakan neraca saldo akhir setelah dilakukan jurnal penutup. 


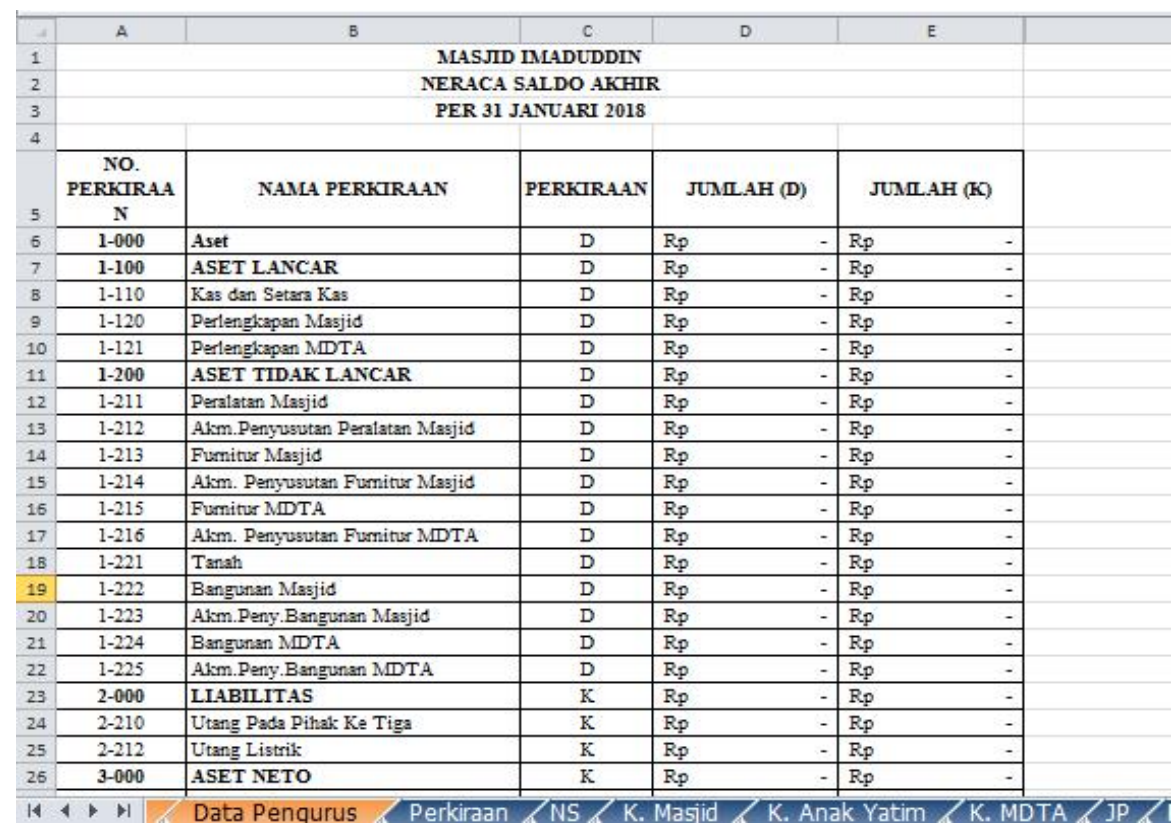

Gambar 16. Format Neraca Saldo Setelah Penutupan

\section{Pembuatan Format Daftar Furnitur Masjid}

Format ini merupakan daftar furnitur yang ada di Masjid

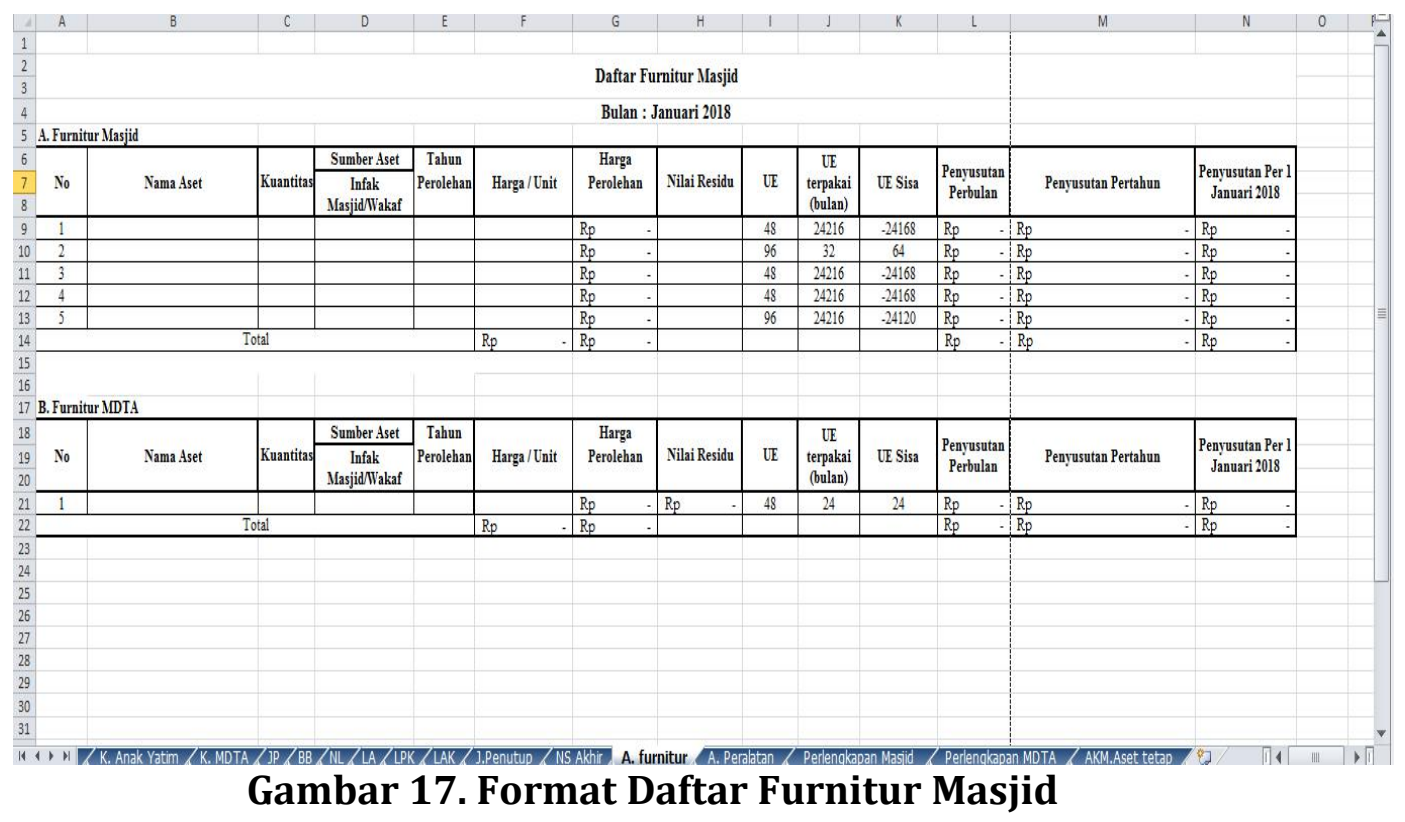

Pembuatan Format Daftar Aset Tetap Masjid

Format ini merupakan daftar aset tetap yang ada di Masjid 


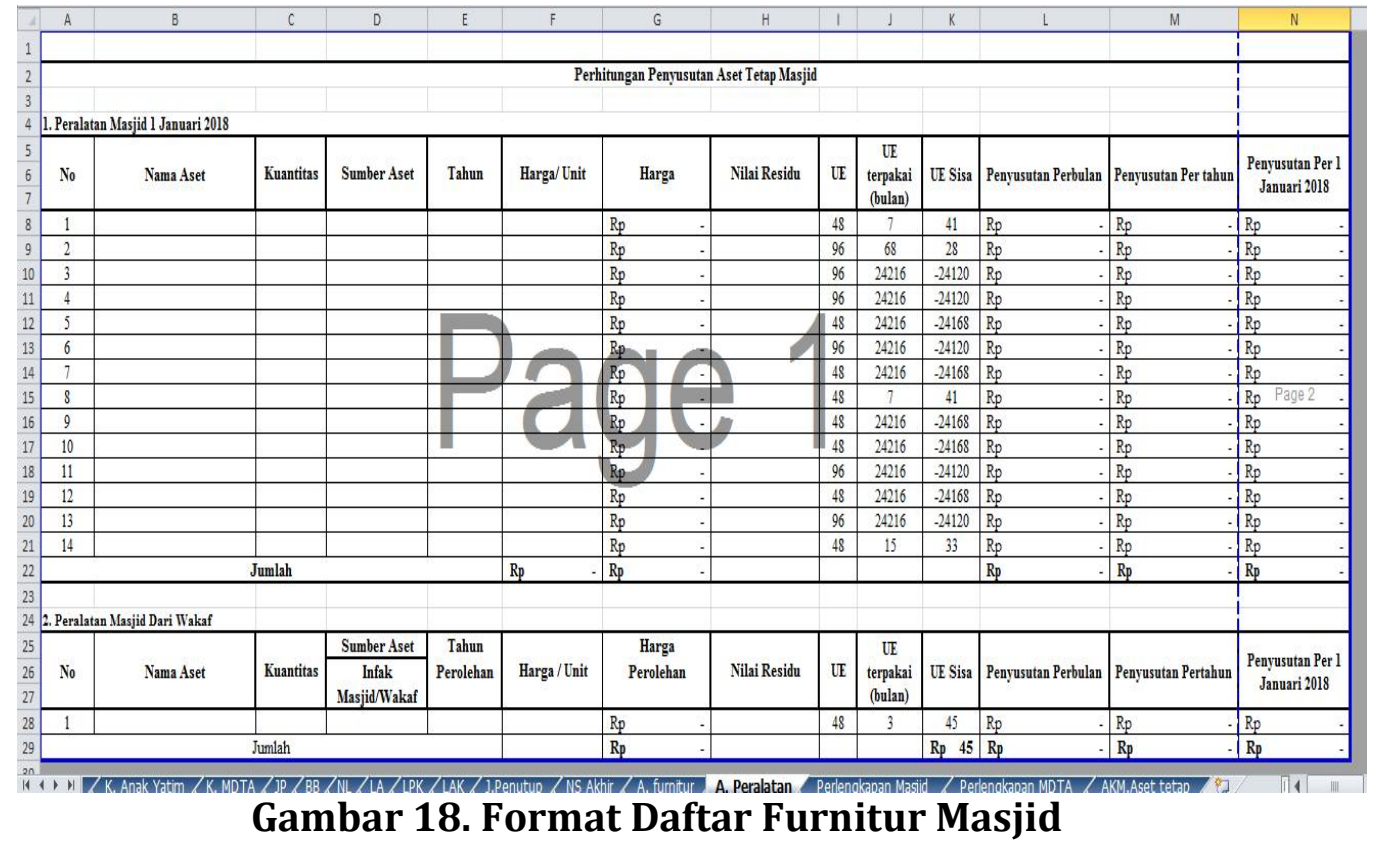

\section{Pembuatan Format Daftar Perlengkapan Masjid}

Format ini merupakan daftar perlengkapan yang ada di Masjid

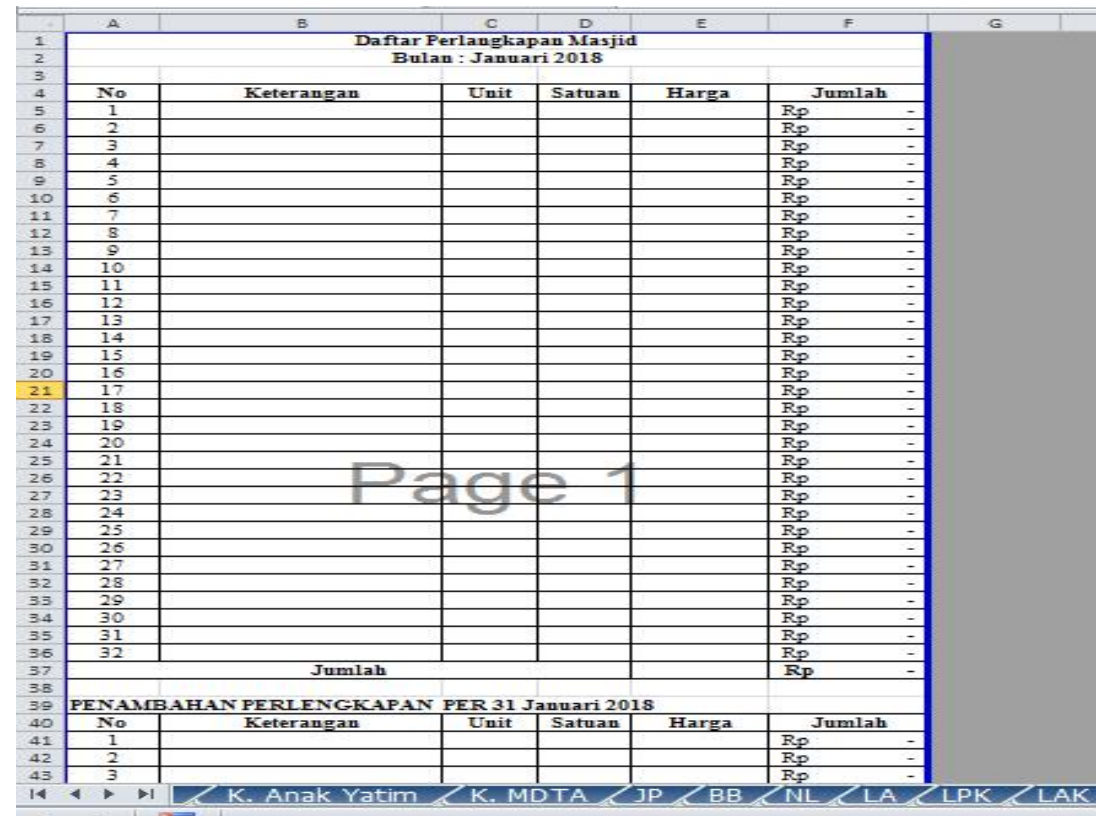

\section{Gambar 19. Format Daftar Perlengkapan Masjid}

\section{Pembuatan Format Daftar Perlengkapan MDTA Masjid}

Format ini merupakan daftar perlengkapan MDTA yang ada di Masjid 


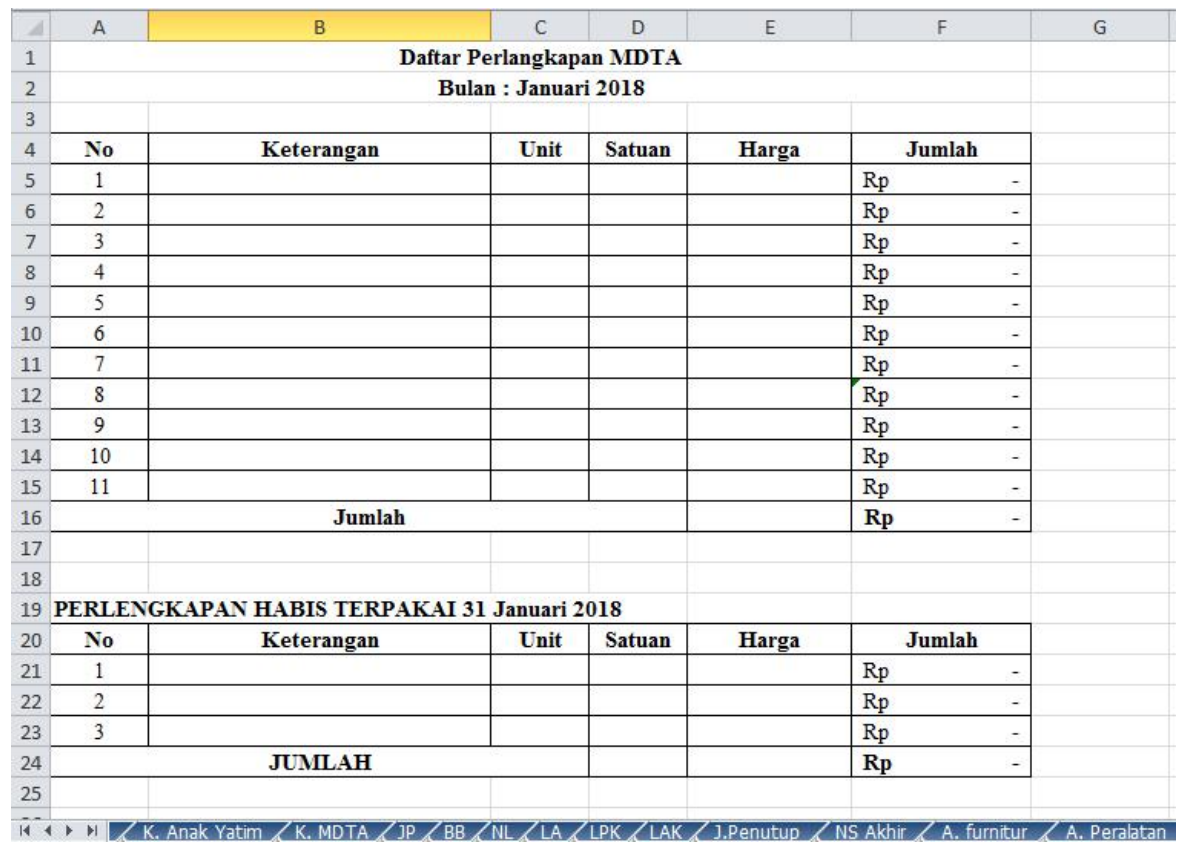

Gambar 20. Format Daftar Perlengkapan MDTA Masjid

\section{Pembuatan Format Daftar Bangunan Masjid}

Format ini merupakan daftar bangunan yang ada di Masjid

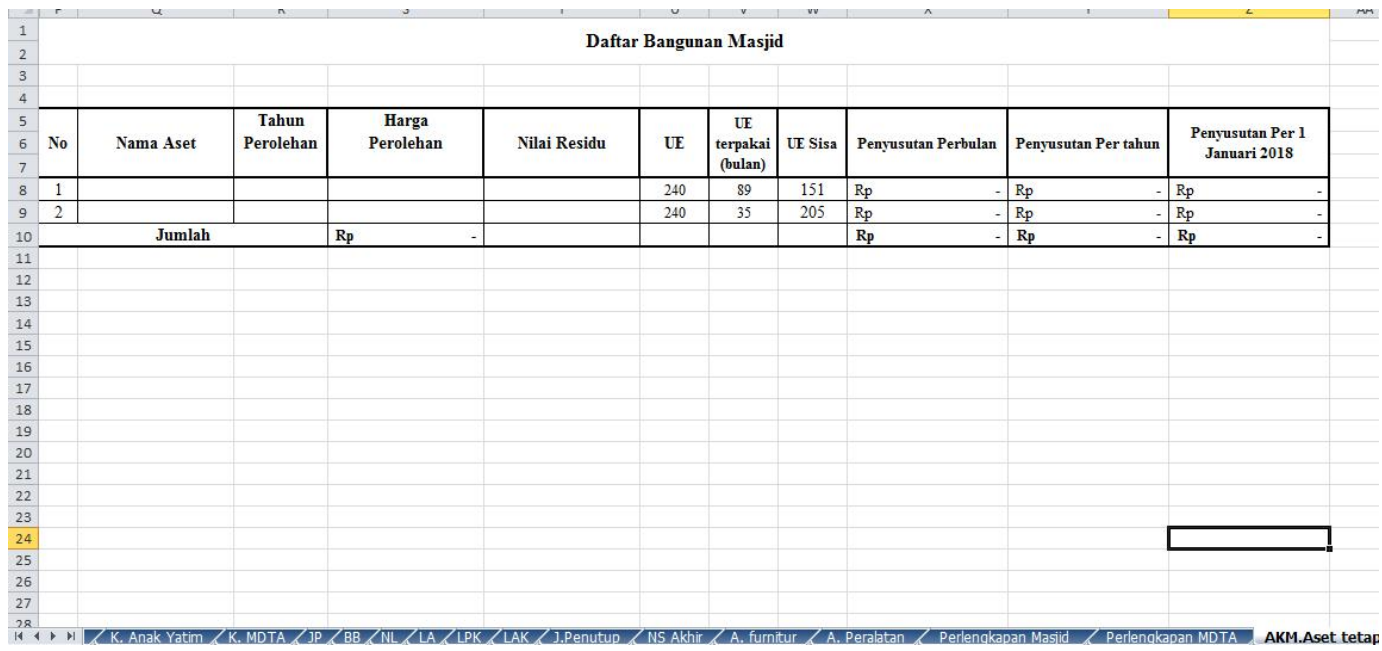

Gambar 21. Format Daftar Bangunan Masjid

\section{Luaran yang Dihasilkan}

Luaran yang dihasilkan adalah :

1. Adanya program aplikasi penyusunan laporan keuangan dengan microsoft excel untuk mitra Masjid Imaduddin.

2. Terlatihnya pengurus mesjid menyusun laporan keuangan menggunakan Excel for Accounting

3. Adanya modul tentang penyusunan laporan keuangan mesjid dengan Excel for Accounting

"Modul Panduan Penyusunan Laporan Keuangan Mesjid". 


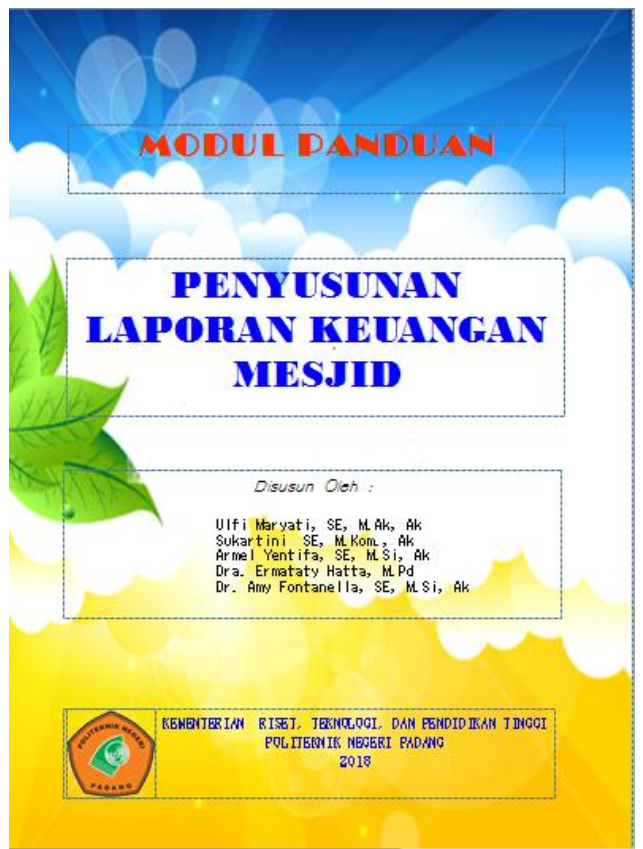

Gambar 22. Modul Panduan Penyusunan Laporan Keuangan Masjid

Didalam modul panduan ini menjelaskan tentang bagaimana cara mengoperasikan rancangan aplikasi yang dibuat serta panduan dalam menginput transaksi keuangan sehingga menghasilkan laporan keuangan mesjid.

\section{Referensi}

Arifin, Johar, Komputer Akuntansi dengan Microsoft Excel, Elexmedia Komputindo, Jakarta, Tahun 2006

DP2M Ristekdikti (2018). Panduan Pelaksanaan Penelitian dan PPM Edisi-XII 2017, Jakarta : Direktorat Riset dan Pengabdian Kepada Masyarakat, Direktorat Jenderal Penguatan Riset dan Pengembangan, Kementerian Riset, Teknologi dan Pendidikan Tinggi.

Ikatan Akuntan Indonesia, Standar Akuntansi Keuangan Entitas Tanpa Akunta-bilitas Publik, Jakarta, 2010

Kusrianto, Adi, Mengupas Tuntas Formula dan Fungsi Microsoft Excel, Elexmedia Komputindo, Jakarta, Tahun 2000

Mahsun, 2006. Ciri-ciri Organisasi Nirlaba, http://sijabatemanuela.ciri-ciri organisasi-nirlaba.html.

Nainggolan, pahala. 2007. Akuntansi Keuangan Yayasan Dan Lembaga Nirlaba Sejenis. Jakarta: PT. Raja Grafindo Persada.

PSAK 45 (Pernyataan Standar Akuntansi Keuangan) Revisi 2017. Pelaporan Keuangan Entitas Nirlaba

Soemarso SR, Akuntansi Suatu Pengantar, Salemba , Jakarta, 2004

Syarifuddin, Program Aplikasi Akuntansi dengan Microsoft Excel, Qowamedia Utama, Solo, Tahun 2004 